\title{
First spermatological study in the Atractotrematidae (Digenea, Haploporoidea): the case of Atractotrema sigani, intestinal parasite of Siganus lineatus
}

\author{
Abdoulaye J. S. Bakhoum ${ }^{1,2}$, Yann Quilichini ${ }^{1, *}$, Jean-Lou Justine ${ }^{3}$, Rodney A. Bray ${ }^{4}$, Jordi Miquel ${ }^{5,6}$, \\ Carlos Feliu $^{5,6}$, Cheikh T. Bâ ${ }^{2}$, and Bernard Marchand ${ }^{1}$ \\ ${ }^{1}$ CNRS-Università di Corsica, UMR 6134-SPE, SERME Service d'Étude et de Recherche en Microscopie Électronique, Corte 20250, \\ Corsica, France \\ 2 Laboratory of Evolutionary Biology, Ecology and Management of Ecosystems, Cheikh Anta Diop University of Dakar, BP 5055, \\ Dakar, Senegal \\ 3 ISYEB, Institut de Systématique, Évolution, Biodiversité (UMR7205 CNRS, EPHE, MNHN, UPMC), Muséum National d'Histoire \\ Naturelle, Sorbonne Universités, CP 51, 55 rue Buffon 75231, Paris cedex 05, France \\ ${ }_{5}^{4}$ Department of Life Sciences, Natural History Museum, Cromwell Road, SW7 5BD London, UK \\ 5 Laboratori de Parasitologia, Departament de Microbiologia i Parasitologia Sanitàries, Facultat de Farmàcia, Universitat de Barcelona, \\ Av. Joan XXIII, sn, 08028 Barcelona, Spain \\ ${ }^{6}$ Institut de Recerca de la Biodiversitat, Facultat de Biologia, Universitat de Barcelona, Av. Diagonal 645, 08028 Barcelona, Spain
}

Received 14 August 2015, Accepted 25 September 2015, Published online 16 October 2015

\begin{abstract}
The ultrastructural organization of the mature spermatozoon of the digenean Atractotrema sigani (from Siganus lineatus off New Caledonia) was investigated by transmission electron microscopy. The male gamete of A. sigani exhibits the general morphology described in digeneans with the presence of two axonemes of different lengths showing the $9+$ " 1 " pattern of the Trepaxonemata, a nucleus, two mitochondria, two bundles of parallel cortical microtubules, external ornamentation, spine-like bodies and granules of glycogen. However, the mature spermatozoon of $A$. sigani has some specific characters such as the morphology of its anterior region and the submembranous electron-dense material. Although similar structures have been reported in some digenean species, the presence of a submembranous electron-dense material describing a complete ring is reported here for the first time in the mature spermatozoon of $A$. sigani. In addition, sperm characteristics are compared between the Haploporoidea and their supposed close superfamilies, and possible phylogenetic implications of these findings for the Digenea are discussed.
\end{abstract}

Key words: Cell Biology, Platyhelminthes, Digenea, Ultrastructure, Spermatozoon, Phylogeny.

\begin{abstract}
Résumé - Première étude spermatologique chez les Atractotrematidae (Digenea, Haploporoidea) : le cas d'Atractotrema sigani, parasite intestinal de Siganus lineatus. L'organisation ultrastructurale du spermatozoïde mûr du digène Atractotrema sigani (parasite de Siganus lineatus en Nouvelle-Calédonie) est décrite au microscope électronique à transmission. Le gamète mâle d'A. sigani présente la morphologie générale des spermatozoïdes décrits chez les digènes avec la présence de deux axonèmes de type $9+$ " 1 " des Trepaxonemata, un noyau, deux mitochondries, deux champs de microtubules corticaux parallèles, une ornementation externe, des corps épineux et des granules de glycogène. Cependant, le spermatozoïde mûr d'A. sigani présente certains caractères spécifiques tels que la morphologie de son extrémité antérieure et le matériel sous-membranaire opaque aux électrons. Bien qu'une structure similaire à cette dernière fût décrite précédemment chez certaines espèces, la présence d'un matériel opaque aux électrons décrivant un anneau complet est observée pour la première fois dans le spermatozoïde de $A$. sigani. De plus, les caractères spermatiques sont comparés entre les Haploporoidea et les superfamilles qui sont censées leur être proches et les possibles implications phylogénétiques de ces résultats pour les Digenea sont discutées.
\end{abstract}

\footnotetext{
*Corresponding author: quilichini@univ-corse.fr
} 


\section{Introduction}

The Atractotrematidae are parasites of the intestine or gall bladder of marine or estuarine teleosts. This family includes four genera, namely Atractotrema, Isorchis, Pseudisorchis and Pseudomegasolena. Atractotrematid species are mainly characterized by the presence of two symmetrical or slightly oblique testes in the hindbody or forebody, vitelline fields with follicles often interconnected as elongate lobes, a hermaphroditic sac enclosing both male and female ducts and a Y-shaped excretory vesicle [37].

The systematic position and taxonomy of the Atractotrematidae still offer challenges at several levels. Previously, the family was considered to be close to the Fellodistomidae [48] or as a synonym of the Haploporidae [1]. However, on the basis of morphological similarities and recent molecular findings, the Atractotrematidae was proposed as a distinct family, closely related to the Haploporidae with which they form the superfamily Haploporoidea [12, 14, 36].

The above historical account indicates the need for a phylogenetic analysis based on an additional, independent set of characters in order to clarify the digenean phylogenetic affinities. In this sense, several authors have proposed ultrastructural characteristics of the mature spermatozoon in digeneans, as is the case in cestodes and monogeneans (the other neodermatan group widely studied) $[6,8,19-21,25,31,33]$.

Spermatological characteristics available in the Haploporoidea concern only the haploporid Saccocoelioides godoyi [11]. In the present study, we describe for the first time the ultrastructure of the male gamete of Atractotrema sigani belonging to the Atractotrematidae.

\section{Materials and methods}

Adult specimens of Atractotrema sigani Durio and Manter, 1969 were obtained from the digestive tract of Siganus lineatus from the fish market of Nouméa, New Caledonia, South Pacific, with the wash method [22]. Voucher specimens were mounted on slides and are kept in the collections of the Muséum National d'Histoire Naturelle, Paris (as MNHN JNC2873) and Natural History Museum, London. For ultrastructural studies, adult digeneans were fixed in cold $\left(4{ }^{\circ} \mathrm{C}\right)$ $2.5 \%$ glutaraldehyde in $0.1 \mathrm{M}$ sodium cacodylate buffer at $\mathrm{pH} 7.2$, rinsed in $0.1 \mathrm{M}$ sodium cacodylate buffer at $\mathrm{pH} 7.2$, post-fixed in cold $\left(4^{\circ} \mathrm{C}\right) 1 \%$ osmium tetroxide in the same buffer for $1 \mathrm{~h}$, dehydrated in ethanol and propylene oxide series, embedded in Spurr resin and polymerized at $60{ }^{\circ} \mathrm{C}$ for $24 \mathrm{~h}$. Ultrathin sections $(60-90 \mathrm{~nm})$ of the seminal vesicle were cut on an ultramicrotome (Power tome PC, RMC Boeckeler ${ }^{\circledR}$ ). The sections were placed on 200 and 300 mesh copper grids and stained with uranyl acetate and lead citrate according to Reynolds' methodology [44]. The cytochemical technique established by Thiéry [47] was also used to locate glycogen in sections placed on gold grids. Finally, all grids were examined on a Hitachi H-7650 transmission electron microscope, operating at an accelerating voltage of $80 \mathrm{kV}$, in the "Service
d'Étude et de Recherche en Microscopie Électronique" of the University of Corsica Pasquale Paoli (Corte, France).

\section{Results}

An analysis of several cross- and longitudinal sections from the seminal receptacle of $A$. sigani has allowed the reconstitution of the mature spermatozoon from the anterior to the posterior extremity. Thus, five regions (I-V) exhibiting different ultrastructural characteristics were distinguished in the male gamete of Atractotrema sigani.

Region I (Figs. 1A-E and 4I) constitutes the anterior part of the spermatozoon showing in longitudinal section a sharp tip (Fig. 1A). In cross-section, the anterior spermatozoon extremity is characterized by the presence of the anterior extremity of the first axoneme and the submembranous electron-dense material which forms a complete ring (Figs. 1A and 4I). Consecutive cross-sections towards the posterior part of region I show the anterior extremity of the second axoneme accompanied by the first axoneme and the submembranous electron-dense material. This latter is reduced and located laterally when both axonemes are completely formed (Figs. 1C-E and 4I).

Region II (Figs. 1F-H and 4II) corresponds to the ornamented area of the mature spermatozoon, showing in several cross-sections the presence of external ornamentation of the plasma membrane, submembranous electron-dense material, the axonemes, first mitochondrion, spine-like bodies and cortical microtubules (Fig. 1F, G). The cortical microtubules (of which the maximum number is about 18) are observed on the side of the mature spermatozoon covered by the external ornamentation, whereas they are absent on the side containing the submembranous electron-dense material (Figs. 1F-H and 4II). Besides the association "cortical microtubules + external ornamentation", it is also interesting to note the progressive reduction of submembranous electron-dense material. In addition, the external ornamentation and submembranous electrondense material are interrupted in the posterior part of this region II.

Region III (Figs. 1I and 4III) is the transitional area before the nuclear region. It is characterized by the presence of only two axonemes and cortical microtubules separated into two fields. Considering the numerous cross-sections showing only these characters, this region appears as a large portion of the mature spermatozoon. In addition, the maximum number of cortical microtubules is reduced from 14 to 17 (Figs. 1I and 4III).

Region IV (Figs. 2A-F and 4IV) is mainly distinguished by the appearance of the second mitochondrion in its anterior part and the nucleus in its middle and posterior part. The anterior part contains only the second mitochondrion, both axonemes and cortical microtubules of which the maximum number (about 9) (Fig. 2A) is lower than in region III. When the nucleus appears in the middle part of this region IV, the axonemes, the second mitochondrial and the two fields of cortical microtubules are still present. However, the maximum number 

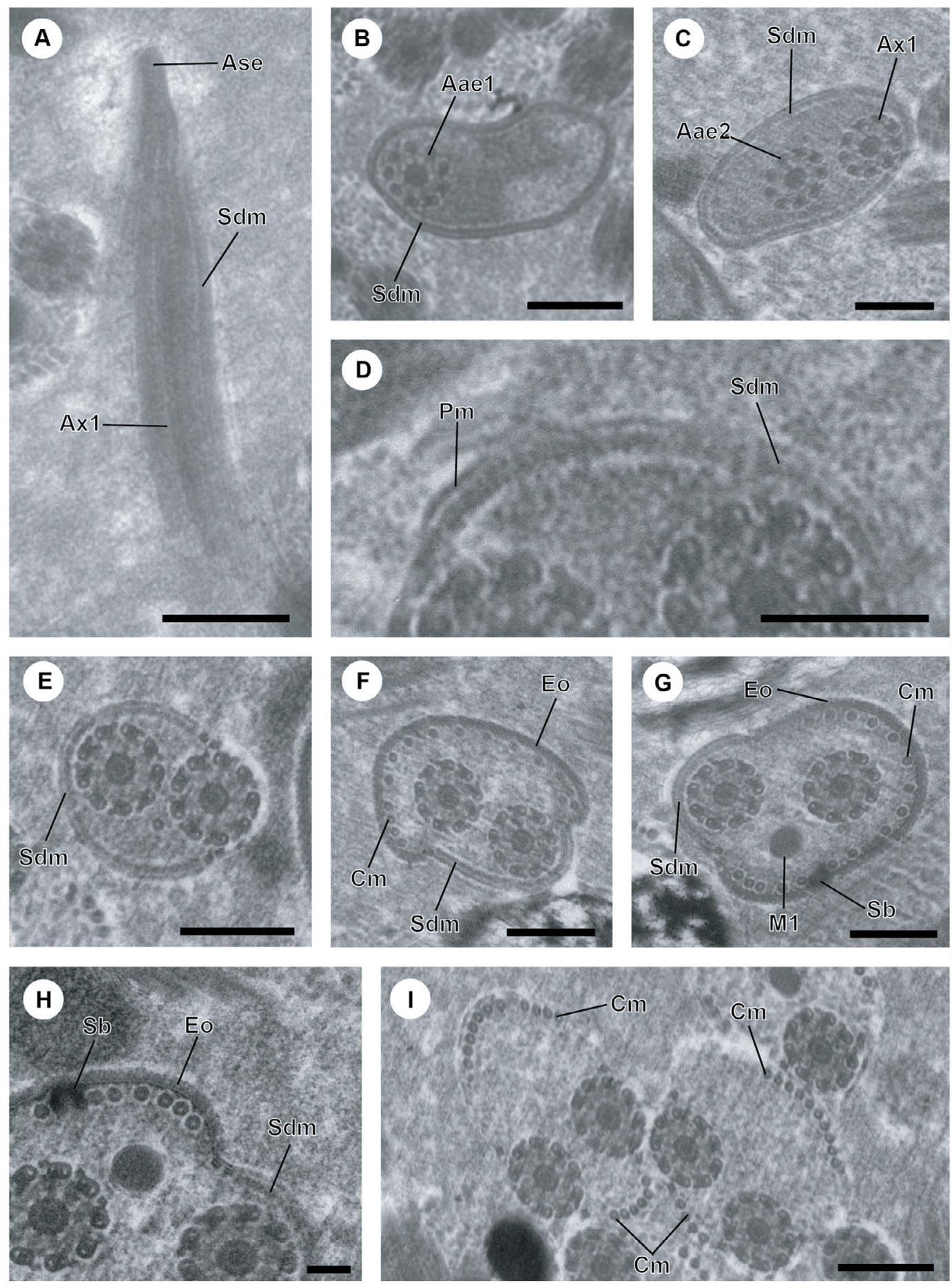

Figure 1. A-I. Mature spermatozoon of Atractotrema sigani in regions I-III. (A) Longitudinal section of anterior spermatozoon extremity (Ase) with a sharp tip. Sdm, submembranous electron-dense material; Ax1 first axoneme. (B) Cross-section showing the anterior extremity of the first axoneme (Aae1) and the submembranous electron-dense material describing a complete ring. (C) Cross-section in region I exhibiting the first axoneme and the anterior extremity of the second axoneme (Aae2). Note also the submembranous electron-dense material surrounding both axonemes. (D) Detail of submembranous electron-dense material of A. sigani. Pm, plasma membrane; Sdm, submembranous electron-dense material. (E) Cross-section in posterior part of region I with the axonemes and the submembranous electrondense material located laterally. (F, G) Consecutive cross-sections in region II characterized by the presence of external ornamentation of the plasma membrane (Eo), the first mitochondrion (M1) and spine-like body ( $\mathrm{Sb}$ ). Note the cortical microtubules (Cm) associated with the external ornamentation and the residual submembranous electron-dense material not associated with cortical microtubules. (H) Detail showing the simultaneous presence of external ornamentation, spine-like body and submembranous electron-dense material. (I) Crosssection in the transitional area prior to the nuclear region, showing the axonemes and cortical microtubules distributed into two fields and their maximum number varies between 14 and 17. Scale in $\mu \mathrm{m}$ : (A, B, C, E, F, G, I), 0.3; (D), 0.2; (H), 0.1 . 

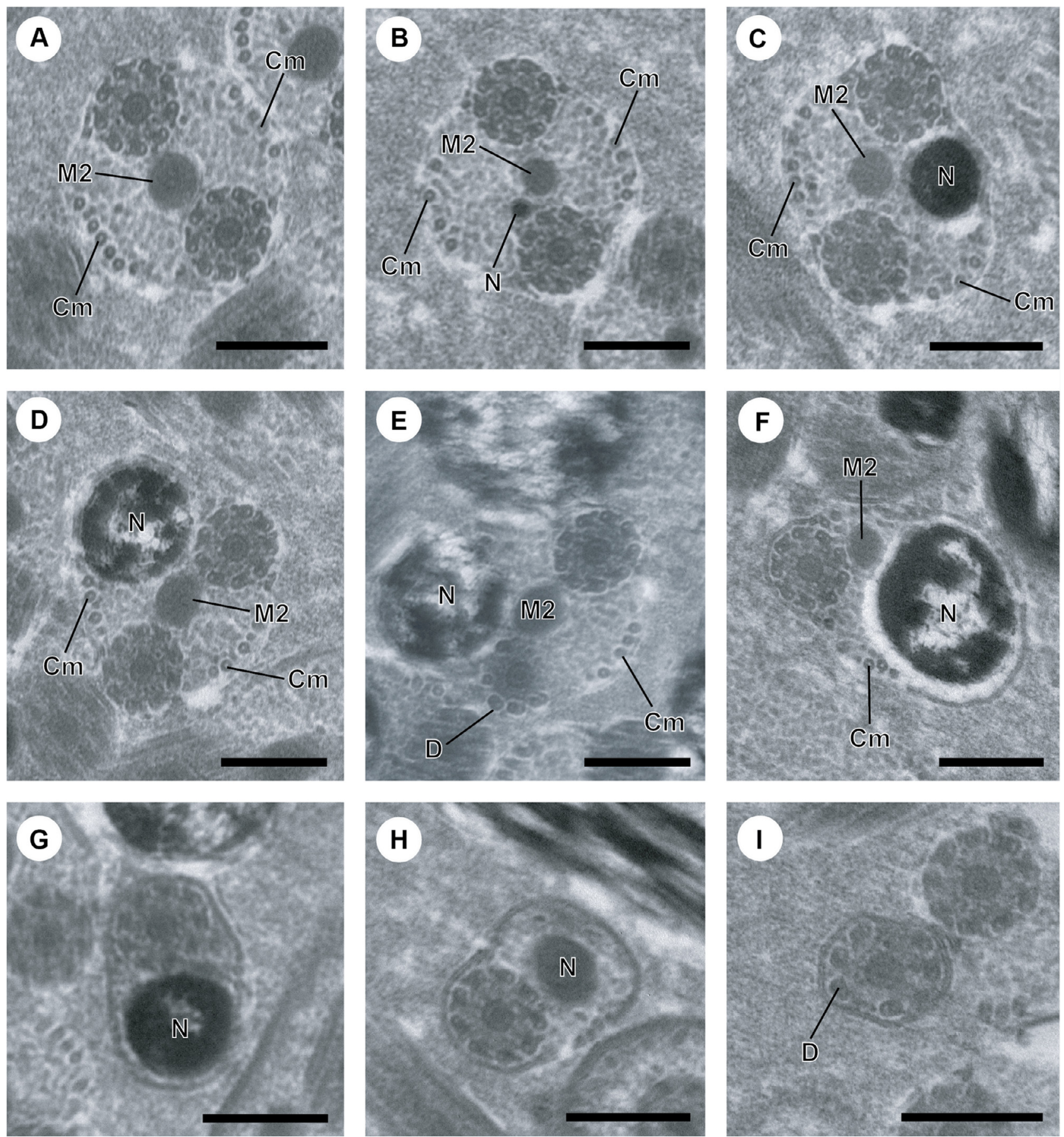

Figure 2. A-I. Mature spermatozoon of Atractotrema sigani in regions IV-V. (A) Cross-section in proximal part of region IV exhibiting the second mitochondrion (M2). Cm, cortical microtubules. Note the decrease in the maximum number of cortical microtubules (about 9) compared to region III. (B-D) Consecutive cross-sections showing the simultaneous presence of the second mitochondrion and the nucleus (N) which increases progressively in size. (E) Disorganization of the first axoneme resulting into doublets of microtubules. D, doublet of microtubules. (F) Distal part of region IV with only the second axoneme, the second mitochondrion and few cortical microtubules (about 4). $(\mathrm{G}, \mathrm{H})$ Cross-section showing only the second axoneme, the nucleus and its progressive reduction in size. (I) Cross-section of the posterior spermatozoon tip, where the nucleus disappears and only one axoneme is still observed. Scale in $\mu \mathrm{m}$ : (A-I), 0.3.

of cortical microtubules progressively diminishes from 9 (Fig. 2B), 8 (Fig. 2C) to 7 (Fig. 2D). Cross-sections in the posterior part of region IV exhibit the posterior extremity of the first axoneme with disorganized doublets of microtubules (Fig. 2E). Consequently, only one axoneme accompanied by the second mitochondrion, nucleus and few cortical microtubules (about 5) are observed (Figs. 2F and 4IV).

Region V (Figs. 2A-D and 4IV) corresponds to the posterior spermatozoon extremity. It is characterized in its proximal part by the presence of the nucleus and one axoneme (Fig. 2G). 

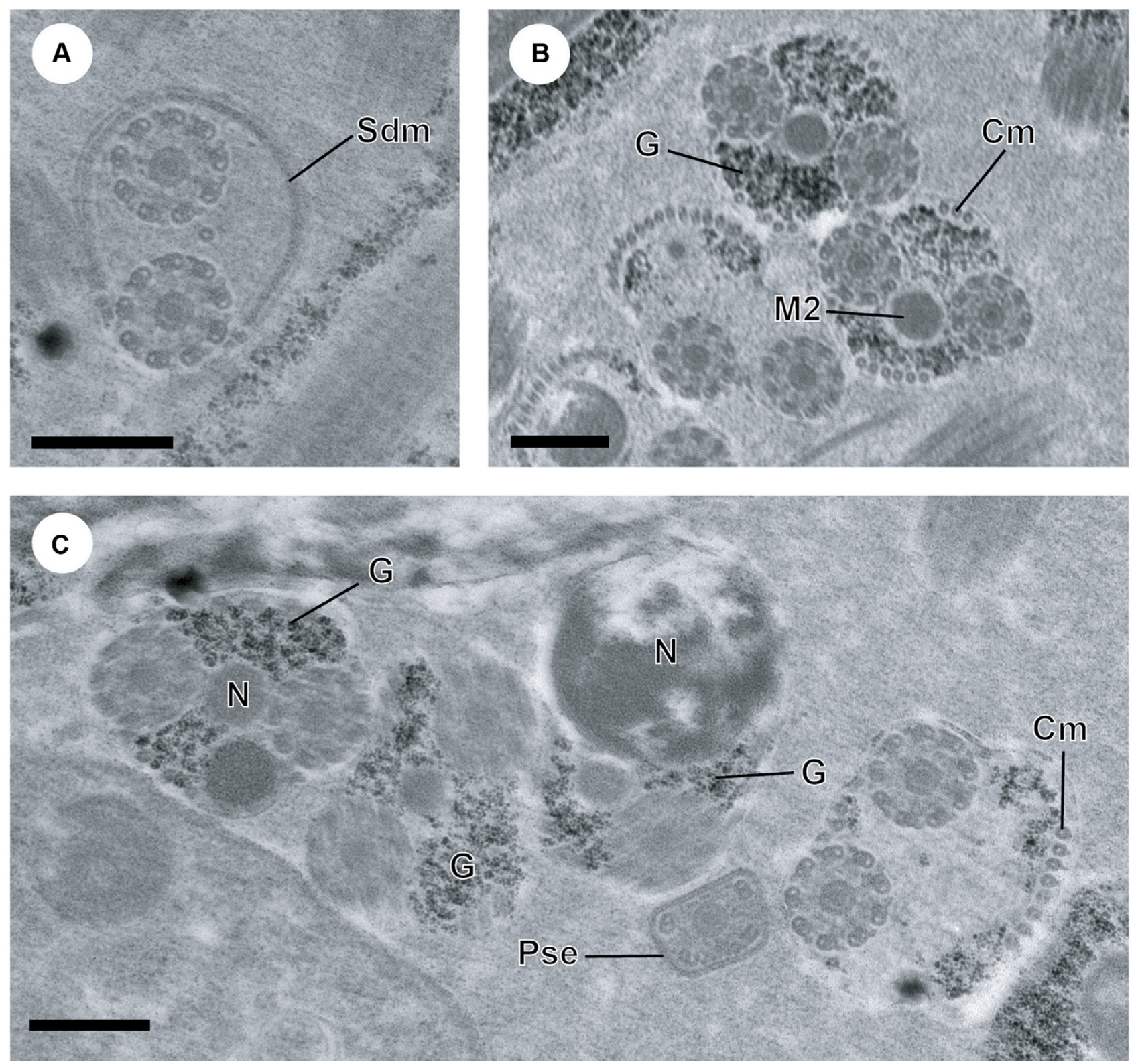

Figure 3. A-C. Cytochemical test of Thiéry (1967) in the spermatozoon of Atractotrema sigani. (A) Transmission electron micrographs showing the absence of granules of glycogen in region I. (B, C) Cross-sections exhibiting the presence of granules of glycogen in regions III-V of the mature spermatozoon of $A$. sigani. Cm, cortical microtubules; G, glycogen granules; M2, second mitochondrion; N, nucleus; Pse, posterior spermatozoon extremity. Scale in $\mu \mathrm{m}$ : (A-C), 0.3 .

Compared to region IV, the second mitochondrion is absent. Moreover, the nucleus and cortical microtubules disappear in the proximal area of this region $\mathrm{V}$. With respect to the distal part of this region, cross-section shows only one axoneme which constitutes the last ultrastructural character in the posterior tip of the mature spermatozoon.

The granules of glycogen irregularly distributed along the mature spermatozoon of $A$. sigani are evidenced by the cytochemical test of Thiéry [47] (Fig. 3A-C). It is interesting to note the absence of glycogen in the anterior spermatozoon extremity (region I) (Fig. 3A).

\section{Discussion}

The ultrastructural organization of the mature spermatozoon of $A$. sigani is in agreement with that reported for most digenean species with the presence of two axonemes of the $9+$ "1" pattern of trepaxonematans [17], nucleus, mitochondria, an association between external ornamentation of the plasma membrane and cortical microtubules, two bundles of parallel cortical microtubules generally arranged in the middle area of the spermatozoon and granules of glycogen irregularly distributed $[3,7,16,26,29,38,40,49]$. 


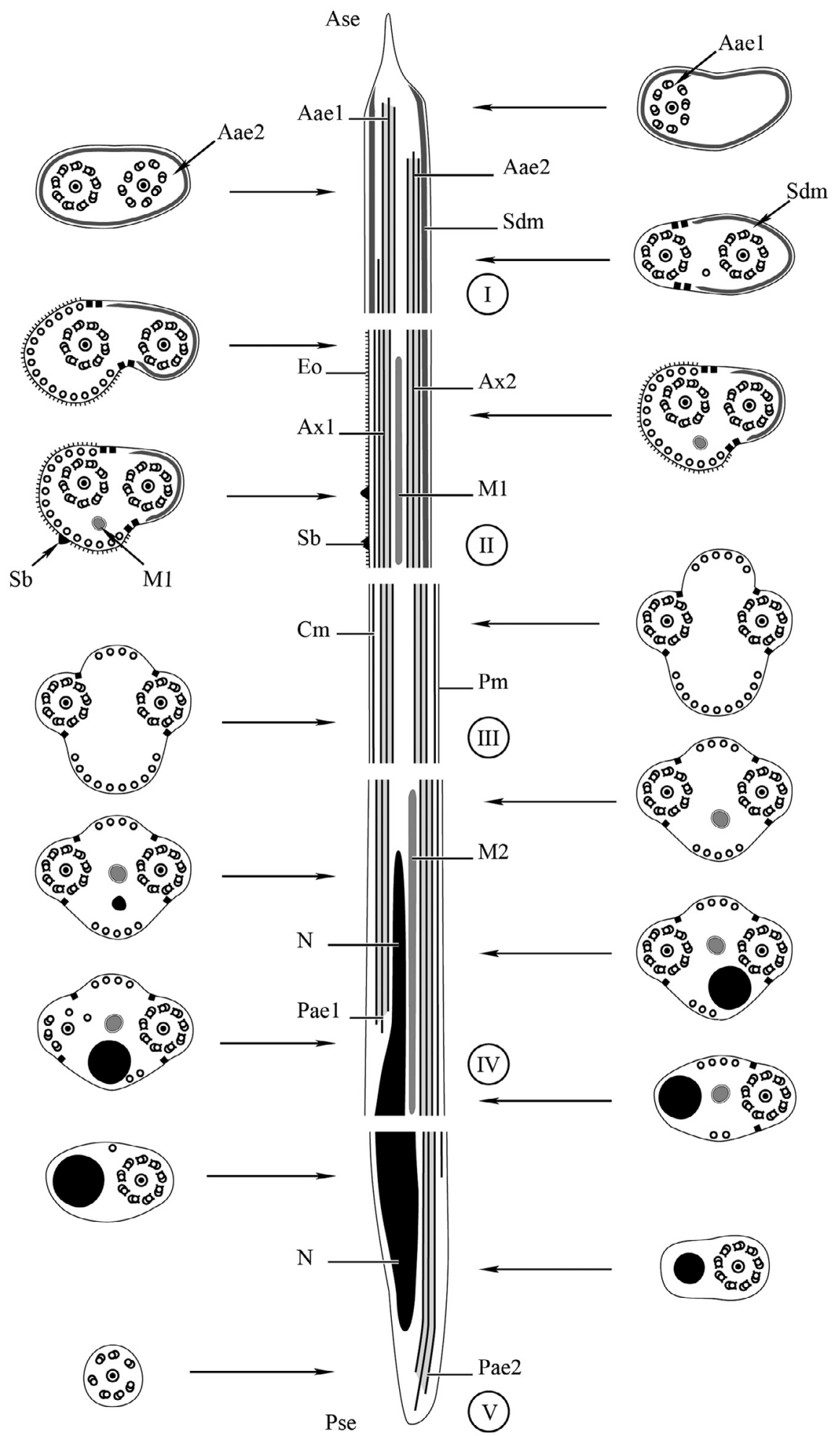

Figure 4. Schematic drawing of the spermatozoon of Atractotrema sigani. Aae1, anterior extremity of first axoneme; Aae2, anterior extremity of second axoneme; Ase, anterior spermatozoon extremity; Ax1, first axoneme; Ax2, second axoneme; Cm, cortical microtubules; Eo, external ornamentation of the plasma membrane; M1, first mitochondrion; M2, second mitochondrion; N, nucleus; Pae1, posterior extremity of axoneme 1; Pae2, posterior extremity of axoneme 2; Pm, plasma membrane; Pse, posterior spermatozoon extremity; Sb, spinelike body; Sdm, submembranous electron-dense material. 
Among the Haploporoidea, only one species, $S$. godoyi, belonging to the Haploporidae has been partially investigated for sperm ultrastructure [11]. Because of the lack of data in $S$. godoyi, no complete comparative study is attempted between its mature spermatozoon and that of $A$. sigani. However, as observed in the sperm cell of $A$. sigani, the male gamete of $S$. godoyi seems to contain two axonemes of the $9+$ "1" pattern of the Trepaxonemata, two bundles of cortical microtubules [11], nucleus and mitochondria. In addition to the classical structures mentioned above, some specific characteristics distinguish the mature spermatozoon of $A$. sigani from those of other digenean taxa.

\section{Particularities of the spermatozoon of $\boldsymbol{A}$. sigani}

The ultrastructural features that characterize the spermatozoon of $A$. sigani are mainly located in the non-nuclear region, especially between the anterior tip and the end of the ornamented area. In fact, the great variety of morphologies and characters observed in the non-nuclear region in digenean spermatozoa might be of great value for phylogenetic considerations [19].

The anterior extremity of the male gamete of A. sigani is characterized by the presence of one axoneme (observed in longitudinal section) and a submembranous electron-dense material. In Digenea, mature spermatozoa exhibiting one axoneme in their anterior extremity are frequent and reported in several families such as the Cryptogonimidae [18, 38, 46], Gyliauchenidae [9, 40], Lepocreadiidae [7, 23, 30], Opisthorchiidae [49] or Plagiorchiidae [32, 34]. Besides the presence of one axoneme, the anterior part of the mature spermatozoon of $A$. sigani also contains submembranous electron-dense material. This latter describes a complete ring surrounding the first axoneme and appears laterally when the second axoneme is completely formed. The complete ring of submembranous electron-dense material is described here, for the first time, in the anterior extremity of the digenean spermatozoa. However, structures like submembranous electron-dense material called also "antero-lateral electron-dense material" or "electron-dense material" (according to the appellation of the authors) have been described previously in digenean spermatozoa belonging, particularly to the superfamily Lepocreadioidea sensu Bray and Cribb [13]. This is the case in Holorchis micracanthum (Aephnidiogenidae), Gyliauchen sp. and Robphildollfusium fratum (Gyliauchenidae), Hypocreadium caputvadum, Neomultitestis aspidogastriformis and $O p$ echona bacillaris (Lepocreadiidae) [2, 7, 9, 23, 30, 35, 40].

An additional peculiarity that distinguishes the mature spermatozoon of $A$. sigani is the absence of cortical microtubules in its anterior extremity and in the side of the submembranous electron-dense material. In fact, the cortical microtubules appear only when both axonemes are completely formed, and they are located on the external ornamentation side.

Compared to the lepocreadioid spermatozoa reported so far, the appearance of cortical microtubules is also noted only when both axonemes are completely formed [7, 30]. However, in the mature spermatozoon of $A$. sigani the submembranous electron-dense material is still observed when cortical microtubules appear and in the ornamented region.

Another specific morphological character of the male gamete of A. sigani concerns the ornamented area. For the first time, the simultaneous presence of external ornamentation of the plasma membrane, cortical microtubules, spine-like bodies and submembranous electron-dense material is described in digenean mature spermatozoa. However, the association "external ornamentation + cortical microtubules + spine-like bodies" observed in the area containing the first mitochondrion has been described previously in other digenean species $[5,6$, $8,15,24,32,35]$.

It is also interesting to notice the location of external ornamentation in the mature spermatozoon of $A$. sigani. In fact, external ornamentation of the plasma membrane appears in the anterior part (region II) of the spermatozoon, where both axonemes are already formed and accompanied by the first mitochondrion. Following the three types of digenean spermatozoa according to the location of external ornamentation established by Quilichini et al. [40], the spermatozoon of A. sigani exhibits type 2, i.e. presence of external ornamentation in the distal part of the anterior spermatozoon, associated with the anterior mitochondrion. Mature spermatozoa with type 2 external ornamentation have also been described so far in other digenean species $[4,7,15,24,30,35]$.

As stated above for the non-nuclear region, the morphology of the posterior spermatozoon extremity presents variability in digenean species and has been proposed as an interesting criterion for phylogenetic analyses [6, 29, 39]. Quilichini et al. [39] were the first to propose three types of posterior spermatozoon morphologies according to the sequence of disappearance of characters towards the posterior tip. Following this criterion, the mature spermatozoon of $A$. sigani exhibits the type 3 or cryptogonimidean type with the sequence "cortical microtubules, nucleus and axoneme". However, considering the numerous variations in the sequences of characters towards the posterior extremity of the spermatozoon observed in digeneans and the lack of such information in several ultrastructural studies, we propose to consider only the terminal character of the male gamete. In this sense, the posterior spermatozoon extremity of $A$. sigani exhibits only one axoneme. This morphology has been observed in most digenean species belonging to the superfamilies Lepocreadioidea (for a review see [30] Table 1), the Microphalloidea (see [29] - Table 1) or Opisthorchioidea $[3,18,38,46]$. The other morphologies reported in digeneans concern spermatozoa with the nucleus at the posterior extremities, as observed in most species belonging to the Paramphistomoidea and Plagiorchioidea [4, 10, 32, 34, 45] and species with posterior spermatozoon tips containing cortical microtubules, as observed in the Opecoelidae and Opistholebetidae [26-28, 39, 41-43].

\section{Possible systematic implications}

The systematic position of the Atractotrematidae is confused. Previously, this family was considered to be close to the Fellodistomidae [48]. The analyses of ultrastructural data available on both families question this classification. In fact, 
the morphology of the mature spermatozoon of the atractotrematid A. sigani (present study) is quite different to that of the fellodistomid Tergestia acanthocephala [24]. The major differences concern (1) the anterior spermatozoon extremity exhibiting one axoneme in $A$. sigani, whereas in T. acanthocephala two axonemes were reported, (2) the posterior spermatozoon extremity containing only one axoneme in $A$. sigani while it contains a nucleus in T. acanthocephala and (3) the presence of the submembranous electron-dense material in A. sigani, whereas it was absent in the mature sperm of T. acanthocephala [24].

More recent systematic approaches based on molecular findings considered the Atractotrematidae to be the sister group of the Haploporidae [12, 14]. Unfortunately, the absence of complete ultrastructural study in the Haploporidae does not allow us to test their close relationship to the Atractotrematidae.

Regarding the position of the Haploporoidea, some molecular analyses have found (with very low support) the Opisthorchioidea as sister group of the Haploporoidea. Moreover, the "clade" Haploporoidea + Opisthorchioidea was found to be close to the Lepocreadioidea [14].

Spermatological studies available in the Opisthorchioidea concern the families Cryptogonimidae, Heterophyidae and Opisthorchiidae. The absence of submembranous electrondense material or similar structures in all opisthorchioid species described so far is an ultrastructural argument that also could question the close affinity between Atractotrematidae and Opisthorchioidea.

However, comparison between mature spermatozoa of A. sigani and those reported in lepocreadioid species has revealed several similarities. They concern the morphology of anterior and posterior spermatozoon extremities, the presence of structure like submembranous electron-dense material, the association "external ornamentation + cortical microtubules", the location of external ornamentation and the spinelike bodies. Although further studies are needed in the unexplored taxa, the ultrastructural characteristics described in A. sigani would suggest a close relationship between the Atractotrematidae and the Lepocreadioidea.

\section{Conclusion}

The present study enlarges the data on ultrastructural studies in the Digenea providing, for the first time, spermatological characteristics in the Atractotrematidae. The mature spermatozoon of $A$. sigani exhibits, as do most digenean species, two axonemes with the $9+$ " 1 " pattern of trepaxonematan platyhelminths, two bundles of parallel cortical microtubules, a nucleus, two mitochondria and granules of glycogen. Besides these ultrastructural features, the male gamete of $A$. sigani contains submembranous electron-dense material located in its anterior region, an association "external ornamentation + cortical microtubules" and spine-like bodies. The particular morphology of the anterior and posterior spermatozoon extremities and that of the submembranous electron-dense material distinguishes the spermatozoa of $A$. sigani from those described in other digenean species.
Regarding the possible phylogenetic implications of our ultrastructural analyses, the present study reveals several similarities between the mature spermatozoa of the atractotrematid A. sigani and those reported in lepocreadioid species. Herein, we suggest a close relationship between the Atractotrematidae and Lepocreadioidea rather than the Opisthorchioidea. However, additional ultrastructural and molecular studies are strongly needed in order to test our hypothesis and understand the relationship between the Atractotrematidae and other digenean families, particularly their most closely related family namely, the Haploporidae.

\section{Conflict of interest}

The Editor-in-Chief of Parasite is one of the authors of this manuscript. COPE (Committee on Publication Ethics, http:// publicationethics.org), to which Parasite adheres, advises special treatment in these cases. In this case, the peer-review process was handled by an Invited Editor, Dominique Vuitton.

Acknowledgements. A.J.S. Bakhoum has a post-doctoral fellowship (No. CE/01/2014) from the "Collectivité Territoriale de Corse Direction de l'Enseignement Supérieur et de la Recherche".

\section{References}

1. Ahmad J. 1985. Studies on digenetic trematodes of marine fishes from the Arabian Sea, off the Panjim Coast, Goa, India. Part 49. On three new haploporid trematodes (Digenea: Haploporidae). Revista Ibérica de Parasitologica, 45, 281-291.

2. Bâ CT, Ndiaye PI, Dione A, Quilichini Y, Marchand B. 2011. Ultrastructure of the spermatozoon of Holorchis micracanthum (Digenea: Lepocreadiidae), an intestinal parasite of Plectorhinchus mediterraneus (Pisces, Teleostei) in Senegal. Parasitology Research, 109, 1099-1106.

3. Bakhoum AJS, Bâ CT, Fournier-Chambrillon C, Torres J, Fournier P, Miquel J. 2009. Spermatozoon ultrastructure of Euryhelmis squamula (Rudolphi, 1819) (Digenea, Opisthorchioidea, Heterophyidae), an intestinal parasite of Mustela vison (Carnivora, Mustelidae). Revista Ibero-latinoamericana de Parasitologia, 68, 37-45.

4. Bakhoum AJS, Bâ CT, Shimalov VV, Torres J, Miquel J. 2011. Spermatological characters of the digenean Rubenstrema exasperatum (Rudolphi, 1819) (Plagiorchioidea, Omphalometridae). Parasitology Research, 108, 1283-1293.

5. Bakhoum AJS, Feliu C, Bâ CT, Miquel J. 2012. Spermiogenesis and spermatozoon of the liver fluke Mediogonimus jourdanei (Microphalloidea: Prosthogonimidae), a parasite of Myodes glareolus (Rodentia: Cricetidae). Folia Parasitologica, 59, $32-42$.

6. Bakhoum AJS, Quilichini Y, Justine J-L, Bray RA, Bâ CT, Marchand B. 2015. Ultrastructural study of sperm cells in Acanthocolpidae: the case of Stephanostomum murielae and Stephanostomoides tenuis (Digenea). PeerJ, 3, e744.

7. Bakhoum AJS, Quilichini Y, Justine J-L, Bray RA, Bâ CT, Marchand B. 2015. Neomultitestis aspidogastriformis Bray and Cribb, 2003 (Digenea, Lepocreadiidae): mature spermatozoon and sperm morpholgies in the Lepocreadioidea. Cell Biology International, 39, 799-807. 
8. Bakhoum AJS, Quilichini Y, Miquel J, Feliu C, Bâ CT, Marchand B. 2014. Collyricloides massanae (Digenea, Collyriclidae): spermatozoon ultrastructure and phylogenetic importance. Parasite, 21, 59.

9. Bakhoum AJS, Sène A, Ndiaye PI, Bâ CT, Miquel J. 2012. Spermiogenesis and the spermatozoon ultrastructure of Robphildollfusium fractum (Digenea: Gyliauchenidae), an intestinal parasite of Sarpa salpa (Pisces: Teleostei). Comptes Rendus Biologies, 335, 435-444.

10. Bakhoum AJS, Torres J, Shimalov VV, Bâ CT, Miquel J. 2011. Spermiogenesis and spermatozoon ultrastructure of Diplodiscus subclavatus (Pallas, 1760) (Paramphistomoidea, Diplodiscidae), an intestinal fluke of the pool frog Rana lessonae (Amphibia, Anura). Parasitology International, 60, 64-74.

11. Baptista-Farias MFD, Kohn A, Cohen SC. 2001. Ultrastructure of spermatogenesis and sperm development in Saccocoelioides godoyi Kohn \& Froes, 1986 (Digenea, Haploporidae). Memórias Instituto Oswaldo Cruz, 96, 61-70.

12. Blasco-Costa I, Balbuena JA, Kostadinova A, Olson PD. 2009. Interrelationships of the Haploporinae (Digenea: Haploporidae): a molecular test of the taxonomic framework based on morphology. Parasitology International, 58, 263-269.

13. Bray RA, Cribb TH. 2012. Reorganisation of the superfamily Lepocreadioidea Odhner, 1905 based on an inferred molecular phylogeny. Systematic Parasitology, 83, 169-177.

14. Bray RA, Cribb TH, Waeschenbach A, Littlewood DTJ. 2014. Molecular evidence that the genus Cadenatella Dollfus, 1946 (Digenea: Plagiorchiida) belongs in the superfamily Haploporoidea Nicoll, 1914. Systematic Parasitology, 89, 15-21.

15. Bruňanská M, Brazova T, Zhokhov AE, Poddubnaya L. 2014. Ultrastructural features of the spermatozoon and its differentiation in Brandesia turgida (Brandes, 1888) (Digenea, Microphalloidea, Pleurogenidae). Parasitology Research, 113, 2483-2491.

16. Diagne PM, Quilichini Y, Bâ CT, Ndiaye PI, Dione A, Marchand B. 2015. Ultrastructure of the spermatozoon of Helicometroides atlanticus (Digenea, Monorchiidae), an intestinal parasite of Parapristipoma octolineatum (Pisces, Teleostei) in Senegal. Tissue \& Cell, 47, 198-204.

17. Ehlers U. 1984. Phylogenetisches System der Plathelminthes. Verhandlungen des Naturwissenschaftlichen Vereins Hamburg, NF, 27, 291-294.

18. Foata J, Quilichini Y, Greani S, Marchand B. 2012. Sperm ultrastructure of the digenean Aphallus tubarium (Rudolphi, 1819) Poche, 1926 (Platyhelminthes, Cryptogonimidae) intestinal parasite of Dentex dentex (Pisces, Teleostei). Tissue \& Cell, 44, 15-21.

19. Justine J-L. 1995. Spermatozoal ultrastructure and phylogeny of the parasitic Platyhelminthes. Mémoires du Muséum National d'Histoire Naturelle, 166, 55-86.

20. Justine J-L. 1998. Spermatozoa as phylogenetic characters for the Eucestoda. Journal of Parasitology, 84, 385-408.

21. Justine J-L. 2003. Ultrastructure des spermatozoïdes et phylogénie des Neodermata, in Taxonomie, écologie et évolution des métazoaires parasites. Combes C, Jourdane J, Editors. PUP: Perpignan, France. p. 359-380.

22. Justine J-L, Briand MJ, Bray RA. 2012. A quick and simple method, usable in the field, for collecting parasites in suitable condition for both morphological and molecular studies. Parasitology Research, 111, 341-351.
23. Kacem H, Bakhoum AJS, Eira C, Neifar L, Miquel J. 2012. Ultrastructural characters of the spermatozoon of the digenean Hypocreadium caputvadum Kacem et al., 2011 (Lepocreadioidea: Lepocreadiidae), an intestinal parasite of Balistes capriscus in Tunisia. Comptes Rendus Biologies, 335, 637-644.

24. Kacem H, Ndiaye PI, Neifar L, Torres J, Miquel J. 2015. Ultrastructure of the spermatozoon of the digenean Tergestia acanthocephala (Stossich, 1887) (Gymnophalloidea: Fellodistomidae): an intestinal parasite of Belone belone gracilis (Pisces: Teleostei). Tissue \& Cell, 47, 235-241.

25. Levron C, Miquel J, Oros M, Scholz T. 2010. Spermatozoa of tapeworms (Platyhelminthes, Eucestoda): advances in ultrastructural and phylogenetic studies. Biological Reviews, 85, 523-543.

26. Levron C, Ternengo S, Marchand B. 2003. Ultrastructure of spermiogenesis and the spermatozoon of Helicometra fasciata (Digenea, Opecoelidae), a parasite of Labrus merula (Pisces, Teleostei). Acta Parasitologica, 48, 255-264.

27. Levron C, Ternengo S, Marchand B. 2004. Spermiogenesis and sperm ultrastructure of Poracanthium furcatum (Digenea, Opecoelidae), a parasite of Mullus surmuletus (Pisces, Teleostei). Acta Parasitologica, 49, 190-200.

28. Miquel J, Nourrisson C, Marchand B. 2000. Ultrastructure of spermiogenesis and the spermatozoon of Opecoeloides furcatus (Trematoda, Digenea, Opecoelidae), a parasite of Mullus barbatus (Pisces, Teleostei). Parasitology Research, 86, 301-310.

29. Miquel J, Vilavella D, Świderski Z, Shimalov VV, Torres J. 2013. Spermatological characteristics of Pleurogenidae (Digenea) inferred from the ultrastructural study of Pleurogenes claviger, Pleurogenoides medians and Prosotocus confusus. Parasite, 20, 28.

30. Ndiaye PI, Bakhoum AJS, Sène A, Diagne PM, Miquel J. 2015. The ultrastructural characters of the mature spermatozoon of Opechona bacillaris (Molin, 1859) (Digenea, Lepocreadiidae) a parasite of Scomber colias Gmelin, 1789 (Scombridae) off the coast of Dakar (Senegal). Acta Zoologica (Stockholm), 96, 91-98.

31. Ndiaye PI, Diagne PM, Sène A, Bakhoum AJS, Miquel J. 2012. Ultrastructure of the spermatozoon of the digenean Lecithocladium excisum (Rudolphi, 1819) (Hemiuroidea: Hemiuridae), a parasite of marine teleosts in Senegal. Folia Parasitologica, 59, 173-178.

32. Ndiaye PI, Quilichini Y, Sène A, Tkach VV, Bâ CT, Marchand B. 2012. Ultrastructural study of the spermatozoon of the digenean Enodiotrema reductum Looss, 1901 (Platyhelminthes, Plagiorchioidea, Plagiorchiidae), parasite of the green turtle Chelonia mydas (Linnaeus, 1758) in Senegal. Parasitology Research, 111, 859-864.

33. Ndiaye PI, Quilichini Y, Sène A, Tkach VV, Bâ CT, Marchand B. 2014. Ultrastructural characters of the spermatozoa in Digeneans of the genus Lecithochirium Lühe, 1901 (Digenea, Hemiuridae), parasites of fishes: comparative study of L. microstomum and L. Musculus. Parasite, 21, 49.

34. Ndiaye PI, Quilichini Y, Tkach VV, Greiman SE, Bâ CT, Marchand B. 2013. Ultrastructure of the spermatozoon of the Digenean Plagiorchis elegans (Rudolphi, 1802) (Plagiorchioidea, Plagiorchiidae). Journal of Morphology, 274, 965-972.

35. Ndiaye PI, Torres J, Eira C, Shimalov VV, Miquel J. 2015. Ultrastructure of the spermatozoon of the trematode Notocotylus noyeri (Digenea: Notocotylidae), a parasite of Microtus arvalis (Rodentia: Cricetidae). Folia Parasitologica, 62, Doi: 10.14411/fp.2015.001. 
36. Olson PD, Cribb TH, Tkach VV, Bray RA, Littlewood DTJ. 2003. Phylogeny and classification of the Digenea (Platyhelminthes: Trematoda). International Journal for Parasitology, 33, 733-755.

37. Overstreet RM, Curran SS. 2005. Family Atractotrematidae Yamaguti, 1939, in Keys to the Trematoda, vol. 2, Jones A, Bray RA, Gibson DI, Editors. CABI Publishing and The Natural History Museum: London. p. 167-174.

38. Quilichini Y, Foata J, Justine J-L, Bray RA, Marchand B. 2009. Sperm ultrastructure of the digenean Siphoderina elongata (Platyhelminthes, Cryptogonimidae) intestinal parasite of $\mathrm{Ne}$ mipterus furcosus (Pisces, Teleostei). Parasitology Research, 105, 87-95.

39. Quilichini Y, Foata J, Justine J-L, Bray RA, Marchand B. 2010. Ultrastructural study of the spermatozoon of Heterolebes maculosus (Digenea, Opistholebetidae), a parasite of the porcupinefish Diodon hystrix (Pisces, Teleostei). Parasitology International, 59, 427-434.

40. Quilichini Y, Foata J, Justine J-L, Bray RA, Marchand B. 2011. Spermatozoon Ultrastructure of Gyliauchen sp. (Digenea: Gyliauchenidae), an intestinal Parasite of Siganus fuscescens (Pisces: Teleostei). Biological Bulletin, 221, 197-205.

41. Quilichini Y, Foata J, Justine J-L, Bray RA, Marchand B. 2011. Sperm ultrastructure of Helicometra epinepheli (Platyhelminthes, Digenea, Opecoelidae), parasite of Epinephelus fasciatus (Pisces, Teleostei). Histology and Histopathology, 26, 1019-1028.

42. Quilichini Y, Foata J, Marchand B. 2007. Ultrastructural study of the spermatozoon of Nicolla testiobliquum (Digenea,
Opecoelidae) parasite of brown trout Salmo trutta (Pisces, Teleostei). Parasitology Research, 101, 1295-1301.

43. Quilichini Y, Foata J, Orsini A, Marchand B. 2007. Spermiogenesis and spermatozoon ultrastructure of Nicolla wisniewskii (Digenea: Opecoelidae), an intestinal parasite of brown trout Salmo trutta (Pisces: Teleostei). Journal of Parasitology, 93, 469-478.

44. Reynolds ES. 1963. The use of lead citrate at high $\mathrm{pH}$ as an electron-opaque stain in electron microscopy. Journal of Cell Biology, 17, 208-212.

45. Seck MT, Marchand B, Bâ CT. 2008. Spermiogenesis and sperm ultrastructure of Cotylophoron cotylophorum (Trematoda, Digenea, Paramphistomidae), a parasite of Bos taurus in Senegal. Parasitology Research, 103, 157-166.

46. Ternengo S, Quilichini Y, Katharios P, Marchand B. 2009. Sperm ultrastructure of the gall bladder fluke Anisocoelium capitellatum (Digenea: Cryptogonimidae), a parasite of Uranoscopus scaber (Pisces: Uranoscopidae). Parasitology Research, 104, 801-807.

47. Thiéry J-P. 1967. Mise en évidence des polysaccharides sur coupes fines en microscopie électronique. Journal de Microscopie, 6, 987-1018.

48. Yamaguti S. 1939. Studies on helminth fauna of Japan. Part. 26. Trematodes of fishes, V. Japanese. Journal of Zoology, 8, 211-230.

49. Zhukova MV, Mordvinov VA, Kiseleva E. 2014. Ultrastructure of spermatozoa in the seminal receptacle of the liver fluke Opisthorchis felineus (Rivolta, 1884). Parasitology Research, 113, 1093-1101.

Cite this article as: Bakhoum AJS, Quilichini Y, Justine J-L, Bray RA, Miquel J, Feliu C, Bâ CT \& Marchand B: First spermatological study in the Atractotrematidae (Digenea, Haploporoidea): the case of Atractotrema sigani, intestinal parasite of Siganus lineatus. Parasite, 2015, 22, 26.

Reviews, articles and short notes may be submitted. Fields include, but are not limited to: general, medical and veterinary parasitology; morphology, including ultrastructure; parasite systematics, including entomology, acarology, helminthology and protistology, and molecular analyses; molecular biology and biochemistry; immunology of parasitic diseases; host-parasite relationships; ecology and life history of parasites; epidemiology; therapeutics; new diagnostic tools.

All papers in Parasite are published in English. Manuscripts should have a broad interest and must not have been published or submitted elsewhere. No limit is imposed on the length of manuscripts.

Parasite (open-access) continues Parasite (print and online editions, 1994-2012) and Annales de Parasitologie Humaine et Comparée (1923-1993) and is the official journal of the Société Française de Parasitologie. 